\title{
The Representation of Women in Thomas Hardy's Tess of the d'Urbervilles
}

\author{
Sabah Abdul Hameed Shakury \\ Department of English, Jadara University, Jordan \\ E-mail: dr_shakury@yahoo.com
}

Received: 22-08-2016

Published: 10-12-2016
Accepted: 12-10-2016

doi:10.7575/aiac.ijalel.v.5n.7p.91
Advance Access Published: November 2016

URL: http://dx.doi.org/10.7575/aiac.ijalel.v.5n.7p.91

\begin{abstract}
This paper is an examination and exploration of Thomas Hardy's representation of women in his novel, Tess of the d'Urbervilles. It provides a brief evaluation of the era in which Hardy was writing, placing emphasis on the psychosexual intricacies of the late Victorian era and their impact upon the characterization of women. The paper also shows Hardy's attitudes toward women and how these attitudes affected his representation of women characters. The picture of vigorous womanhood and a victim of forces beyond control is clearly portrayed in Tess, the heroine. Women are presented as sensual creatures and weak. Hardy portrays women affected by the pressure exerted on them by their environment and heredity. Due to their humanity, suffering is inevitable and guilt is a common compassion.
\end{abstract}

Keywords: Tess, sensual, patriarchal, Victorian, representation, independence, identity

\section{Introduction}

The writing of novels about women characters was a popular trend during the late nineteenth and early twentieth centuries. Thomas Hardy followed that trend to advance women's rights, but the publication of his Tess of the d'Urbervilles in 1891 shocked Victorian readers because of the novel's sexual themes and his pessimistic outlook.

In order to explore the nature of Hardy's insight to women, one must examine problems which surround his representation of women in this novel, such as the popular image of women in the Victorian era and the pervasive cultural image of the 'angel in the house' contrasts with the image of the fallen woman and other less conventional images of woman.

Most feminist critics would agree that women are the central figures in Hardy's works. Pamela Jekel writes, "Hardy focuses primarily on the feminine" (1), and Rosalind Miles also observes that women form Hardy's "starting point" that they are "the summit of his highest endeavor, his initial inspiration and his ultimate goal"(44).

Thomas Hardy's Tess of the d'Urbervilles is a study of the development of woman character in self, identity and independence. With the help of his young woman, Tess, Hardy exposes his strong plea for justice and charity. He exposes his feelings against the Victorian manners and morals when he defends Tess. He tends to idealize her on occasion, but he does not spoil the essentials. Tess remains a child of nature, good but not too good. In a sense, she is beyond good and evil because of her generosity which is more real than the encompassing moralities. Tess can endure her sorrows; she can forgive the wrongs done to her, but not to forgive herself. As one critic remarks:

Mr. Hardy's heroines are characterized by a yielding to circumstance that is limited by the play of instinct. They are never quite bad. It seems, indeed, that this quality in them, which shuts them out from any high level of goodness, is precisely that which saves them from ever being very bad. They have an instinctive self-respect, an instinctive purity. (Ellis 117)

Hardy's Tess of the d'Urbervilles is also a study a woman's personal experience, as portrayed in the context of the novel, and how Tess, the heroine, is presented as a fresh, innocent, naive country girl, who is ruled by emotion rather than by intellect, placing her in accordance with Victorian expectations for women. We learn that Tess is a dutiful daughter, willing to sacrifice nearly anything for her family.

Tess is one of Hardy's most distinctive heroines which is considered as an archetypal character. She is at the end of a long line of d'Urbervilles, who becomes a searcher in search of her own past, but she is caught between two worlds: her innocent youth and her incipient womanhood.

Hardy, through all the events and characters presented in a way, tries to offer a vivid portrayal of women at the Victorian era in which women were attempting to redefine their place in society, trying to leave the domestic sphere to work and the realm of man. They were fighting for equality and Hardy was a supporter of this movement. He brilliantly portrays the destructive attitude of man to woman. Hardy's portrayal of woman is so interesting because of his 
compassionate concern about their welfare. As Harvey Curtis Weber comments:

He maintained that it was unjust to make marriage the only career open to women and favored women's suffrage at a time when suffragettes were generally viewed as annoying oddities. He complained of the unrealistically sheltered education young girls received at teacher's [sic] college. ... He approved a woman's resolve to go by her own rather than her husband's name. (193)

Hardy presents Tess as a confused woman in her emotions, her duties and her sense of self-preservation. She is afraid to tell Alec that she holds no attraction to him, so that she remains docile to all that circumstance which brings her to crucial moments in the novel.

Hardy's novel, Tess of the d'Urbervilles, is the story of a maiden who turned to a woman. It is a story of Tess's journey from youth to maturity, through time and earth, in search of self and a place in the earth. It is about how this young innocent young woman tries to manage her affairs and establishes better human condition through work, through redemption from the past and its moral consciousness. But soon all innocence is lost and the inner evil, which exists within human, overpowers, and what we see is the image of woman oppressed by the patriarchal system.

Though Hardy exposes the abuses in the system, he shows that women fall short of the qualities of their language and intelligence. Lovely Tess is simple, naive, and impulsive; she appears revolutionary and bizarre. In her, one may feel a sense of woman who is not capable of the duties required for establishing intellectual human communities. The novel also highlights how Hardy tries to advance women's rights by showing to what extent women were degraded in Victorian England. He sympathizes with his heroine through his presentation of analogous male and female characters.

Hardy has brilliantly shown the innate nature of woman. Carl J. Weber, in his Hardy of Wessex, quotes Hardy himself: "The majority of women are quite worthy enough in nature to satisfy any reasonable being" (94), but these women are in desire of equality in marriage, independence and opportunities for personal fulfillment. Hardy has a great interest of his women characters, whether they are elderly ladies or young women. The depth of his characterization suggests his great interest. He gives careful attention to clothing, jewels, cosmetics, and other small features, as well as in describing the emotional reactions. His knowledge apparently gained by observing many types of women around him. Irving Howe, in his studies of Hardy's novels, states that Hardy "liked women" and "could not imagine a universe without an active, even an intruding feminine principle" (108).

\section{Discussion}

From the very beginning of the novel, we can find traces of the impact of the patriarchal culture on Hardy and his portrayal of women as being less intelligent. Tess is shown as inferior to the men in her life. Consistently contributing to her own misfortune, she impulsively and senselessly murders Alec. Besides, atypical woman appears in Tess of the d'Urbervilles. The image of Tess is radical. She is increasingly aggressive; she has some acts against society. Tess is the first woman of the Wessex Tales to strike out against a man she hates. Her retaliation, like her behavior, is prompted by blind impulse, not creative, intellectual sense of obligation to herself.

The limiting views of women's images which Hardy's heroine, Tess, encounters in the course of the story function to prevent her from achieving a coherent moral vision. Thus, Hardy, through the novel, exposes the effect of conventional morality and limiting images of women. The heroine, Tess, strives to generate a wider realm of action and a broader expression of her sexuality than her context will allow her. She denied terms of self-definition. She rebels against social expectation, insisting rather on exploring the boundaries of female conformity.

However, Tess is one of Hardy's most sympathetic characters. As a seduced woman, she is 'bad' in the eyes of Victorian society as well as in her own eyes, but as Hardy followed the trend to advance women's rights, he portrayed this 'helpless maiden' in such a way to gain the sympathy of his readers. Tess's strong sense of self and integrity is another positive aspect that persuades the reader to admire her, as a woman. She displays this self-regard in her interactions with Angel. She cannot keep her past a secret from her lover; she must reveal who she truly is, though, as Jekel argues, "Tess realizes that her confession may kill Angel, and she will surely lose his love. Though she does not want to lose him, her moral demons and her strong hopes drive her to confess" (166). On the other hand, the reader senses that Tess is not totally innocent, naïve, or clever. She commits murder. She is a sinner according to Victorian mores, and she must be punished.

In spite of the flaws of his women characters, Hardy deals with them objectively which make them interesting and possible. Tess is awarded some valuable characteristics which make it nearly impossible for readers to disfavor her. She has an acute feminine beauty that attracts the notice of her passers-by who "would wonder if they would ever see her again" (Tess 10). Hardy, here, of course purposefully demonstrates her beauty and fascination. As Robert B. Heilman claims, "Hardy goes out of his way to establish the beauty and womanliness of Tess" (Introduction xi).

Early in the novel, Hardy describes Tess's beauty mixed with innocence, "phases of her childhood lurked in her aspect still. As she walked along to-day, for all her bouncing handsome womanliness, you could sometimes see her twelfth year in her cheeks, or her ninth sparkle from her eyes: and even her fifth would flit over the curves of her mouth now and then" (Tess 9). This positive introduction to the leading woman in the novel moves the attention and admiration to Tess, the heroine. Then Hardy presents Tess to his readers by showing her other admirable personality traits, such as her first words in the novel when she defends her drunken father, telling her fellow classmates, "Look here; I won't walk 
another inch with you, if you say any jokes about him" (Tess 9), or her resolution and loyalty when she refuses to allow others to criticize her family or name. Finally, Tess's acceptance of guilt, her submission to her family's wishes, and her resolution to their decision illustrate her respectable personality. Besides, in this accurate representation of women, Hardy may have learned the secrets of the female heart which are not revealed to the average man.

At the start, everything seems to be at peace. The lovely Tess first appears in a fertility dance in the Vale of Blake moor, a "fertile and sheltered tract of country in which the fields are never brown and the springs never dry"(6). She appears as a sexual being when she carries a bouquet of white flowers in her left hand and a peeled willow wand in her right. Her voice is typically female -- naive, irrational, emotional. Her appeal is of a sensual rather than ethereal nature.

Although Hardy obviously loved his women characters, he allowed some of them, like Tess, to meet tragic ends or to suffer greatly, because he had his own views about the realities of women's nature and life. He sometimes portrays women as weak which cause them to fail or be seriously hindered in achieving their liberation. He portrays them as victims of their tendencies.

He presents Tess as a victim in so many ways to gain the reader's sympathy with her. She appears as a victim when she attempts to be honest with her husband and the result is her dismissal. As Heilman comments:

(Hardy) does not center the story on Angel, the potential tragic hero, but

On Tess, whom he pities deeply because she is ill treated by Alec and Angel,

by Farmer Groby, by the timing of events, by weather and the job situation,

by accidents and a death, by distance and legal facts, by a host of afflictions

that it would take much good luck to survive. (Introduction xi)

Hardy's presentation of Tess as a victim evokes pity and in turn incites the reader's sympathy for her pain.

Tess, as Hardy portrays her in the novel, is a victim of many forces. As Janis P. Stout explains:

She is seen, as she will continue to be seen throughout the novel, as being caught

up in overwhelming forces, and is the victim of her father's shiftlessness and

both parent's false hopes even before she becomes the victim of Alec D'Urbervilles

stratagems. She is a victim, too, of her own good nature, her readiness to

sympathize with her family's plight and to go along with their foolish schemes for

betterment, and indeed a victim of her own body's early maturation, before

she has had a chance to develop for herself the wariness that her mother fails to

provide her. (239)

But Helen Follet remarks that "His judgments of women are censorious in the extreme; indeed, his favorite motif is the situation which might be of ideal felicity but for a woman's failure in constancy or candor" (130).

Hardy saw women's life in the late nineteenth century hard, though women were gaining some career opportunities. He urged the need for sympathy and help for women to achieve their fulfillments. As Charles Henry Duffin remarks, Hardy "saw life as a very hard school, and if the women suffer more than men it may be because woman is the weaker vessel. ... It is not Hardy who treats women cruelly, but life -- life as Hardy saw it" (238).

Hardy shows Tess, in the novel, as the only character who has the tendency toward self-sacrifice. He portrays and calls her in the title page of the Wessex edition of the novel as a 'pure woman' with admirable characteristics, spiritual purity and physical attraction. He portrays her as an innocent character who lives in an environment that betrays her at every turn. He seems to say that even nature brings about her downfall. She lacks hardness, though she is basically kind, to defend herself at some critical situations. When Angel deserts her, Tess determines to bear the strain and sorrow of it and not to tell anybody about her troubles and that to bring no blame on Angel. She leaves her family and tries to work to support herself. Her misery increases until she finds the wounded pheasants who have the relativity of sorrows which help her to endure her troubles. She says, "Poor darlings --- to suppose myself the most miserable being on earth in the sight o' such misery as yours!” (Tess 274).

A critic, Evelyin Hardy, also remarks that "Hardy could penetrate a woman's mind and interpret her thoughts as well as he could his own" and adds that he often wrote from the woman's point of view (65). Tess has serious concern for her family, for abstract concepts of right and wrong, and for social standards. But the main problem, as Duffin remarks “... her mind had the touch of yieldingness that was just necessary to allow the touch of animalism in her flesh to respond to great external pressure" (220).

Alec seduced Tess because of her attraction which keeps him returning to her until he wins her again for a brief time. Tess and Angel are initially attracted to each other physically, although their later love is based on other qualities. After Angel departs for Brazil, Tess's love for him becomes almost asexual. Tess, like any heroine of Victorian literature, shows her love for Angel with full steadfastness and self-denial. She adores him as it seems as a godlike deity. She avoids other admirers and bandages her face and cuts her eyebrows. When she seems ugly, she says: 
O no --- I don't care! I'll always be ugly now, because Angel is not here, and I

have nobody to take care of me. My husband that was is gone away, and never will love me anymore; but I love him just the same, and hate all other men, and like to make 'em think scornfully of me!" (Tess 275)

But when Angel comes back and asks Tess to join him, her moral sense is shattered by his return, her anger at Alec's betrayal increases, so that she stabs and kills Alec in order to prove to Angel that she loves him and not her seducer, explaining to Angel, "I was unable to bear your not loving me! say you do now, dear, dear husband ... now that I've killed him!" (304). She kills Alec because it becomes necessary after she hears Angel, before leaving her, says: "How can we live together while the man lives? ... he being your husband in Nature, and not I? If he were dead it might be different..." (239).

Then Tess spends an idyllic five days with Angel when Alec has gone, but she fears that Angel's devotion may not last, "I would rather be dead and buried when the time comes for you to despise me. ... considering what my life has been I cannot see why any man should, sooner or later, be able to help despising me ...'”(382). When Tess realizes that her remaining time is short, she makes no effort to escape her fate, "It is as it should be. ... This happiness could not have lasted. ... now I shall not live for you (Angel) to despise me'”(388). Then Tess's reply to her executioners, “"I am ready,", (388) seems typical of her responses in all critical situations.

Self-sacrifice occurs frequently among Hardy's women. Tess suffers because she possesses this characteristic. She is a serious woman, carries the tendency to become a death seeker. She finds life difficult because she is too receptive to experience in an inhospitable world. She is weak because she becomes vulnerable to, and enslaved by, her almost delirious love for a particular man. Yet, she never falls into the category of the weak, simpering heroine. Tess has individuality and resourcefulness, but never to the extent that she is not inevitably destroyed by her refusal to compromise her expectations to what is expected by the world of commonsense categories, and proprieties.

\section{Conclusion}

Hardy's novel, Tess of the d'Urbervilles, at the end, appears to be a success, a success of the portrayal of female character, which is perhaps considered as Hardy's greatest contribution to English literature. Women are the outstanding figures in all of his novels. Some critics, indeed, state that Hardy's presentation of women characters is more effective than his presentations of men. In spite of the flaws of his women characters, Hardy deals with them objectively which make them interesting and possible. As Duffin remarks, Hardy is "almost a specialist in women" (235).

Tess of the d'Urbervilles represents an ever-increasing growth of disdain and frustration with the Victorian formulaic views of women. Hardy, through the novel, stands against those who interfere in the lives and desires of women in his time. Through the character of Tess, he shows the value of all women and the pain women endure when society interferes with their heartfelt aspirations.

In creating Tess, Hardy strongly protests against the harsh and unfair treatment of Victorian society for women. He blames society for Tess's dissatisfaction and tragedy, and she is free from any blame. As Jane Thomas asserts, "Hardy recognized women's physical, mental and emotional susceptibility to convention and their consequent capitulation in the face of apparently overwhelming social pressures" (49). Tess is the symbol of an age-old wrong, a tragedy of women, of nature and of society. She gives the impression of being larger than the fate itself. She expresses Hardy's feelings towards women and, in one respect, towards society. His feeling is shown when he defends Tess against the Victorian manners and morals. He succeeds in that the reader is outraged at the unjust treatment of Tess by her society. Angel Clare represents the harsh reactions of society against her.

Hardy's creation of Tess is a sharp condemnation of Victorian social morality. As Jekel relates, "He (Hardy) creates a powerful sympathy and reader identification with Tess and her situation and thereby questions social morality and her fate at the hands of that morality" (158). Of course, Hardy tries to reveal the hypocrisy and shallowness of the society's beliefs by twisting the Victorian view of good and evil. He demonstrates how society forms such images of women and reveals, through his novel, his strong motivation to change the Victorian society's opinion of women. In the novel, Tess evidently struggles between the expected role and the real self. While she suffers emotional dilemmas, she seems to experience harsh circumstances as a result of the social expectations placed upon her. Such unpleasant events win reader's sympathy and work to break down the traditional views of women. Anyhow, Hardy's Tess of the d'Urbervilles proves his growing frustration with his contemporaries and his desire to improve the condition and status of women in his time.

At the end, though this novel was rejected by many Victorians, Hardy could expose his vivid portrayal of women and his strong plea for justice and charity. By showing the suffering of women, Hardy has demonstrated the need for change. His novels, especially Tess of the d'Urbervilles, earned him temporary disdain among his fellow men, but lifelong celebrity and admiration by his future readers.

\section{References}

Duffin, Charles Henry. Thomas Hardy: A Study of the Wessex Novels, the poems, and the Dynasts. Manchester: University Press, 1973. 
Ellis, Havelock; Cox, R. G.; Southam, B. C.. Thomas Hardy, 1995, p115-137, Follet, Helen. Some Modern Novelists. Free Port, New York: Books for libraries Press, 1918.

Hardy, Evelyn. Thomas Hardy: A Critical Biography. London: Hogarth Press, 1954.

Hardy, Thomas. Tess of the D’Urbervilles. York Press,Lebanon, 1988.

Heilman, Rober B. Thomas Hardy: Introduction. New York: Bantam Classic, 1992.

Howe, Irving. Studies of Hardy's Novels. New York: Macmillan, 1967.

Jekel, Pamela L. Thomas Hardy's Heroines: A Chorus of Priorities. Troy, NY: Whitson, 1986.

Miles, Roslind. "Women of Wessex." The Novels of Thomas Hardy. Ed. Anne Smith. New York: Barnes \& Noble. 1979. 23-44.

Stout, Janis P. "The Fallen Women and The Conflicted Author: Hawthorne and Hardy's American Transcendental Quarterly, 3 (1987): 233-46.

Thomas, Jane. Thomas Hardy, Femininity and Dissent: Reassessing the Minor Novels. New York: St. Martin's, 1999.

Weber, Carl J. Hardy of Wesessex. New York: Columbia University Press, 1950.

Webster, Harvey Curtis. On a Darkling Plain: The Art and Thought of Thomas Hardy. Chicago: University of Chicago Press, 1947. 